\title{
SELECTION OF JAPANESE QUAIL FOR RESISTANCE TO HYPODYNAMY AND PHYSIOLOGICAL CONSEQUENCES OF SELECTION
}

\author{
M. JURÁNI, P. VÝBOH, D. LAMOŠOVA, L. KOŠTÁL, K. BOḊA, V. SABO \\ Institute of Animal Biochemistry and Genetics SAS,90028 Ivanka pri Dunaji, Slovak Republic
}

Received July 31, 1995

Accepted June 6, 1996

\begin{abstract}
Juráni M.,P. Výboh, D. Lamošová, L. Koštál, K. Bođa, V. Sabo:Selection of Japanese Quail for Resistance to Hypodynamy and Physiological Consequences of Selection. Acta vet. Brno 1996, 65: 57-64.

Japanese quail line resistant to hypodynamy have been selected during 12 generations. Cumulative egg-production throughout 14 days lasting hypodynamy was used as the selection criterion. In each generation one half of quail with the highest egg-laying was chosen to the subsequent generation. The average egg-production during hypodynamy in selected line was higher than in control. There was a small decrease in body weight detected in the selected line during hypodynamy, but food intake was increased. Egg weight, especially the egg shell weight, fertility and hatchability was in selected line higher in course of rearing. There were significant differences in response of the endocrine system represented by hormones (catecholamines, corticosterone, thyroid hormones, estradiol) and some indicators of intermediary metabolism (protein, glucose, cholesterol, triacylglycerols, polyunsaturated fatty acids) between nonselected and selected line of Japanesequail to short hypodynamy treatment.
\end{abstract}

Japanese quail, endocrine and metabolic profile, egg, selected line, nonselected line

The Japanese quail in Earth conditions shows a fair number of performance qualities, the most important being the high coefficient of feed conversion into the egg proteins. From this aspect an inclusion of the Japanese quail in a closed spaceship ecosystem was considered, with the aim to provide food for astronauts (B o d a 1993).

In order to survive in specific conditions of space flights, such as weightlessness and limited space, an organism must be able of quick adaptation. In Earth condition the hypodynamy simulates the weightlessness in space and is usually used in experiments of similar type (Kovalenko 1977). Obviously the reactions of neurohumoral system have been used as indicator of normal or stressogenic situation of organism.

From this point of view the reaction of Japanese quail neurohumoral system to the short term hypodynamy, i.e. suspension of Japanese quail in jackets for $4 \mathrm{~h}$, was studied. In a series of experiments the content of serotonin and catecholamines in several parts of brain and in the different structures of hypothalamus, which were studied in detail, were shown to be changed (Ju ráni et al. 1981; 1984; 1989). There was an increased concentration of serotonin in hypothalamus during short time hypodynamy. On the other hand, concentration of catecholamines decreased as well as concentration of cAMP in the same region of brain. The highest decrease of noradrenaline was demonstrated in the $n$. periventricularis magnocellularis and $\mathrm{n}$. medialis posterior. Restraint resulted in increase of catecholamines, corticosterone and prolactin in plasma, and in a decrease of thyroid and gonadal steroids levels.

Longer lasting hypodynamy ( 21 days) did not have the same consequences (Ju ráni et al. 1980). Content of catecholamines in hypothalamus on the 14th day of hypodynamy increased. The level of catecholamines, corticosterone and thyroid hormones was normalized after 14-21 days. On the same days the concentration of estradiol in plasma was still decreased. In these experiments the effect of hypodynamy on egg laying was studied. During the first 3 days, the egg production fell and on the 6th day it reached a minimum. Later on, there was a successive rise in egg production and towards day 21 it represented about $60 \%$ of the initial egg production before the treatment. 
To examine the effects of long lasting hypodynamy on viability, an extremely long lasting experiment in which quail were subjected to 90 days of hypodynamy was performed. During the first days of hypodynamy the picture of neuroendocrine reaction was very similar to previous experiment ( Ju ráni et al. 1983). If the hypodynamy was prolonged from 30 days to 60 days, the content of hypothalamic catecholamines, and plasma concentration of catecholamines, corticosterone and thyroxine $\left(\mathrm{T}_{4}\right)$ corresponded to the pre-treatment levels of these neuroendocrine parameters. Triiodothyronine $\left(\mathrm{T}_{3}\right)$ level was still increased. In this experiment estradiol was decreased most markedly on the 5th day but then slightly increased from 30 to 60 days. This elevation was accompanied by higher egg laying, which was after an initial decrease elevated to $82 \%$ of the initial level. Similarly to previous experiments the large individual variability of Japanese quail response to hypodynamy was observed, mainly in egg production during the first days of hypodynamy. This led us to the idea of genetic project - the selection of quail line resistant to hypodynamy.

\section{Materials and Methods}

\section{Selection program}

The parental population was obtained by crossing the randombred and inbred quail line from our Institute. To form the quail line resistant to hypodynamy, adult hens ( 80 birds) were exposed to 14 days hypodynamy in tight jackets. Egg-laying was recorded every day. Cumulative egg production during hypodynamy served as the selection criterion. In each generation $50 \%$ of hens with the highest number of laid eggs during this treatment were mated with cocks to form the subsequent generation. Twelve successive generations were bred according to this scheme. Nonselected line is represented by twelve randombred mated generations of original quail population.

\section{Experimental procedure}

Japanese quail from both lines were kept and fed by standard method. Body weight of hens was recorded weekly (during the hypodynamy only at the start and end). During hypodynamy, egg production and food intake was recorded every day.

Eighty quail of selected and nonselected lines were kept under normal conditions. Egg laying was recorded during the first 3 month from the onset of egg laying. At the end of this period egg weight and egg shells of both lines were compared and from 100 incubated eggs fertility and hatchability were estimated.

In the second experiment 40 hens from each line were assigned to five groups: control and groups exposed to hypodynamy lasting $30 \mathrm{~min}, 1,2$ and $4 \mathrm{~h}$ ( 8 animals from each line in each group). Birds were decapitated immediately after the hypodynamy. The blood from head (for estimation of catecholamines) and body (for estimation of other physiological parameters) was collected for determination of catecholamines by radioenzymatic method (IRPAR kit, Czech Republic), corticosterone by radioimmunoassay (RIA) according to the method of Etche s (1976), thyroxine and triiodothyronine by RIA method of Föld es et al. (1978), estradiol by RIA method of Frá nek and Hru ska (1980), protein according the method of Lowry et al. (1951), glucose (Merck kit, FRG), triacylglycerols and cholesterol (Boehringer Mannheim kits, FRG) and polyunsaturated fatty acid according to the method of B arash and A kow (1987). Data from the second experiment were analyzed by two-way ANOVA, assessing the effects of line and hypodynamy duration, followed by Duncan's test.

\section{Results and Discussion}

Japanese quail is frequently used in selection experiments owing to its short generation interval. Examples of such selection programs are for example divergent selection for growth under split and complete nutritional environments (D a ren and Marks 1988), for blood corticosterone response to immobilisation (S a t t erle e and John s on 1988), or for resistance or susceptibility to an acute normobaric hypoxic challenge (B a r tels et al. 1985).

Twelve generations of selection for high egg-laying during hypodynamy affected the selected line in different production and physiological parameters. The time course of egg production as a response to 14 days lasting hypodynamy has changed as a consequence of selection. In the 12th generation the average egg laying in selected line decreased to the minimum value $27 \%$ within 3 days after the onset of hypodynamy, while in control line to $0 \%$ within 6 days. At the end of hypodynamy the egg production in selected line recovered to the initial value $(100 \%)$, while in control line only to about $40 \%$ (Fig. 1). 
Cumulative egg production during the 14 days lasting hypodynamy increased substantially over the twelve generations of selection from $24 \%$ in original population to $82 \%$ in the 12th generation (Fig. 2). In nonselected line it remained at the same initial level.
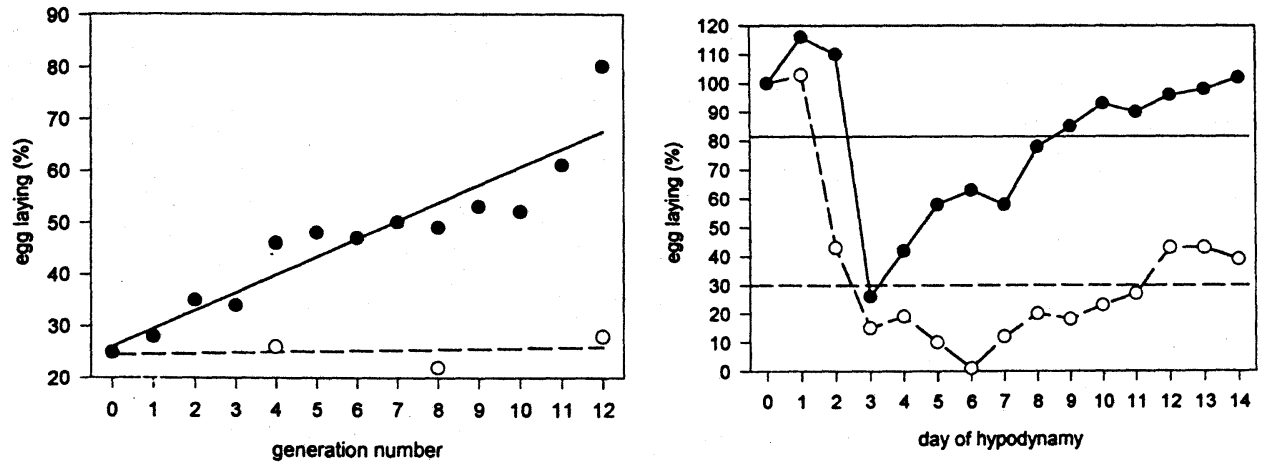

Fig. 1. Quail egg-laying dynamics during hypodynamy of Fig. 2. Mean egg production of quail during hypodythe 12th generation

Open circles - nonselected line

Full circles - selected line $\mathrm{n}=80$ namy in course of selection process Open circles - nonselected line Full circles - selected line $\mathrm{n}=80$

Better adaptation to the hypodynamy challenge in selected quail is also documented by the minimal loss of body weight during hypodynamy. There was a marked decrease in body weight during 14 days treatment in control line (Fig. 3). On the other hand, the food intake was higher in selected line during the whole 14 days of hypodynamy (Fig. 4). This higher food intake is probably connected with the significantly higher egg-production.

Selection did not affected only the egg-laying during hypodynamy, but also the egg-laying under normal conditions. Average egg-laying during the first 3 month of egg-laying peri-

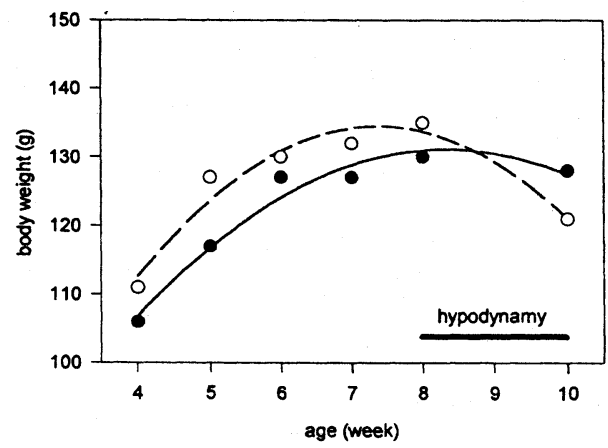

Fig. 3. Growth-rate curves of quail during development and effect of hypodynamy Open circles - nonselected line

Full circles - selected line $\mathrm{n}=80$

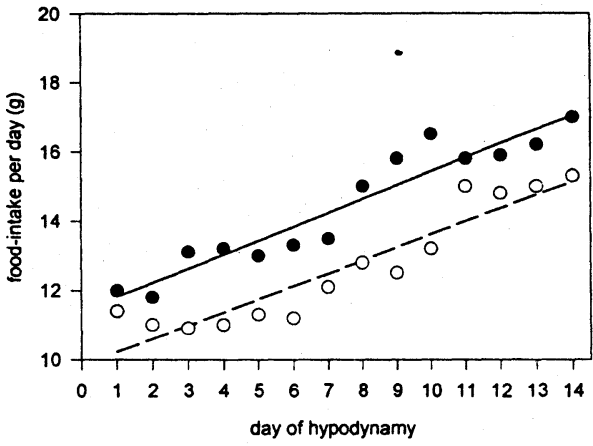

Fig. 4. Food-intake of quail per day during hypodynamy

Open circles - nonselected line

Full circles - selected line $\mathrm{n}=80$

od was in the 12th generation of selected line higher by $12 \%$ in comparison with nonselected line ( $94 \%$ vs. $82 \%$ ). The egg weight, especially the weight of the egg shell, were also significantly increased $(6.8 \%)$. Other parameters improved by selection were fertility and hatchibility of eggs $(83.9 \%$ vs. $75.5 \% ; 83.1 \%$ vs. $78.9 \%)$. 
To study the changes in endocrine response to hypodynamy adult quail of both lines were subjected to short-term hypodynamy. Hypodynamy induced the increase of catecholamines. Quail from nonselected lines responded to $2 \mathrm{~h}$ hypodynamy by a significant increase of plas-

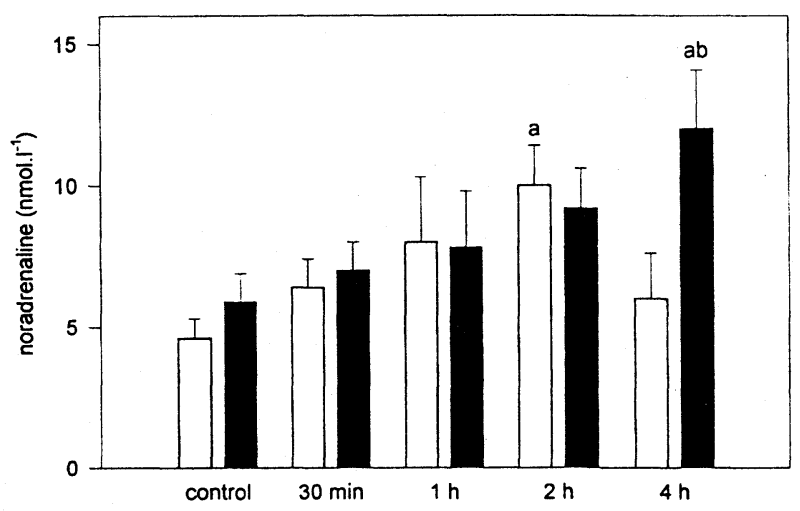

Fig. 5. Effect of hypodynamy on plasma noradrenaline concentration (mean + S. E. M.)

Open bars - nonselected line

Full bars - selected line

$\mathrm{n}=8$

$\mathrm{a}-\mathrm{p}<0.05$ in comparison with control within single line

$\mathrm{b}-\mathrm{p}<0.05$ in comparison with nonselected line

er in selected line in comparison to nonselected line.

The basal levels of $T_{4}$ and $T_{3}$ did not differ between both lines. After the exposure of

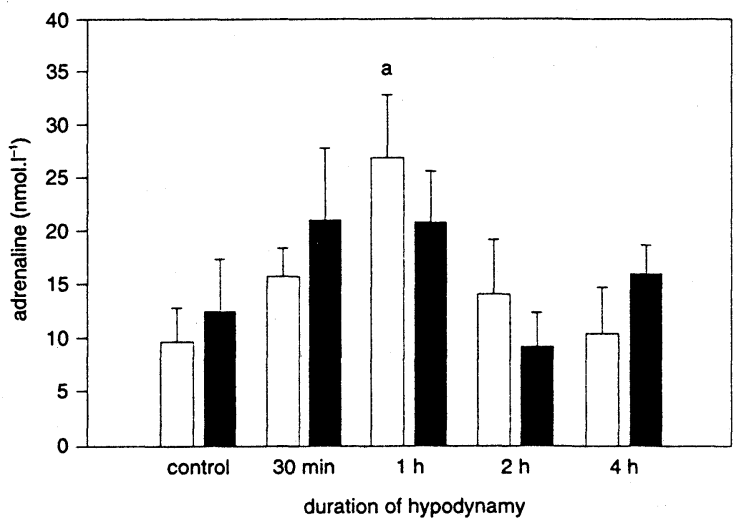

Fig. 6. Effect of hypodynamy on plasma adrenaline concentration $($ mean + S. E. M.)

Open bars - nonselected line

Full bars - selected line

$\mathrm{n}=8$

$\mathrm{a}-\mathrm{p}<0.05$ in comparison with control within single line ma noradrenaline (Fig. 5).

The increase was delayed by $2 \mathrm{~h}$ in selected quail. While in nonselected line the significant increase of adrenaline level was recorded after $1 \mathrm{~h}$, in the selected line the level was not changed significantly throughout the whole experiment (Fig. 6).

The basal level of corticosterone in plasma was higher in selected line of quail (Fig. 7). After $30 \mathrm{~min}$ exposure to hypodynamy plasma corticosterone increased rapidly in both lines and remained at the high level. After $4 \mathrm{~h}$ exposition to hypodynamy was still highquail to $30 \mathrm{~min}$ and $2 \mathrm{~h}$ lasting hypodynamy significant decline of plasma $\mathrm{T}_{4}$ was recorded in nonselected birds (Fig. 8). In selected quails the decrease of plasma $\mathrm{T}_{4}$ concentration occurred after 2 and $4 \mathrm{~h}$. Level of $T_{3}$ was not affected by hypodynamy (Fig. 9). The only between line differences were determined after $30 \mathrm{~min}$ and $2 \mathrm{~h}$ treatment.

There were no significant differences in plasma estradiol levels between nonselected and selected lines except $4 \mathrm{~h}$ (Fig. 10). All tested hypodynamy durations caused significant decreases in plasma estradiol of nonselected line. In selected quail the decline was not significant. This results are in agreement with our previous 


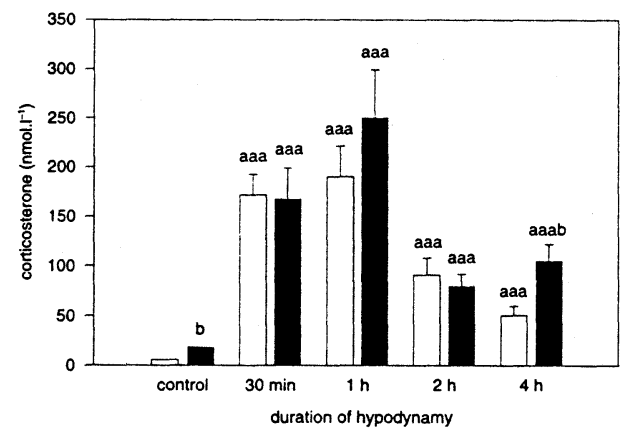

Fig. 7. Effect of hypodynamy on plasma corticosterone concentration (mean + S. E. M.)

Open bars - nonselected line

Full bars - selected line

$\mathrm{n}=8$

aaa $-\mathrm{p}<0.001$ in comparison with control within single line

$\mathrm{b}-\mathrm{p}<0.05$ in comparison with nonselected line

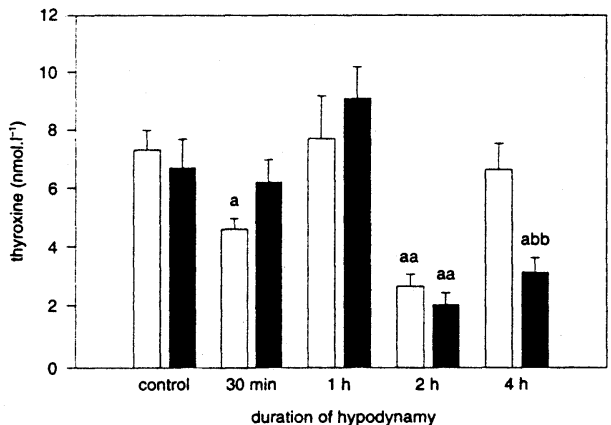

Fig. 8. Effect of hypodynamy on plasma thyroxine concentration (mean + S. E. M.)

Open bars - nonselected line

Full bars - selected line

$\mathrm{n}=8$

$\mathrm{a}-\mathrm{p}<0.05$ in comparison with control within single line

aa $-\mathrm{p}<0.01$ in comparison with control within single line

$\mathrm{b}-\mathrm{p}<0.05$ in comparison with nonselected line

data (J u rá $\mathrm{n}$ i et al. 1983) and indicate the close relation between the estradiol levels and egg-production.

The basal levels of proteins in serum were very similar in both lines (Fig. 11). During the hypodynamy the level of proteins slowly declined. The decrease was faster in nonselected line and it was significant in case of 2 and $4 \mathrm{~h}$ hypodynamy. In selected quail decrease of serum proteins occurred after $4 \mathrm{~h}$ lasting hypodynamy only.

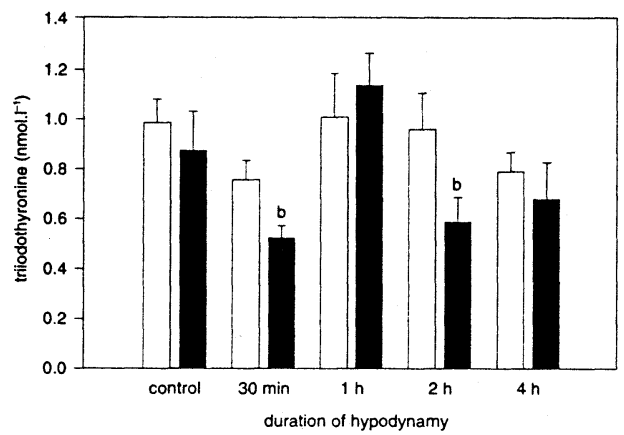

Fig. 9. Effect of hypodynamy on plasmatic triiodothyronine concentration (mean + S. E. M.)

Open bars - nonselected line

Full bars - selected line

$\mathrm{n}=8$

$\mathrm{b}-\mathrm{p}<0.05$ in comparison with nonselected line

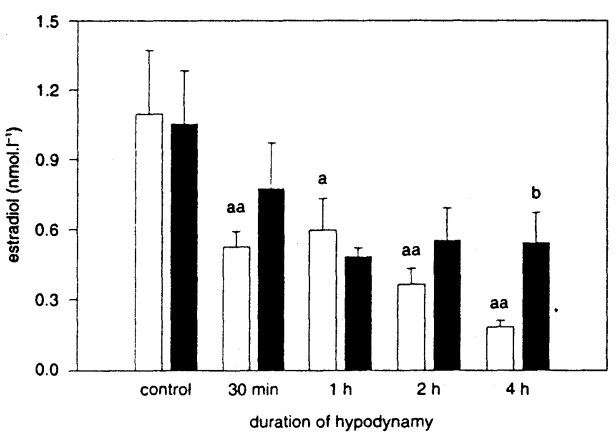

Fig. 10. Effect of hypodynamy on plasma estradiol concentration (mean + S. E. M.)

Open bars - nonselected line

Full bars - selected line

$\mathrm{n}=8$

$\mathrm{a}-\mathrm{p}<0.05$ in comparison with control within single line

aa $-\mathrm{p}<0.01$ in comparison with control within single line

$\mathrm{b}-\mathrm{p}<0.05$ in comparison with nonselected line

The basal levels of glucose differed between both lines (Fig. 12). In nonselected line the glucose concentration was higher and the significant increase was found after 30 minutes and $2 \mathrm{~h}$ of hypodynamy. The increase of plasma glucose in selected quail was not significant. 


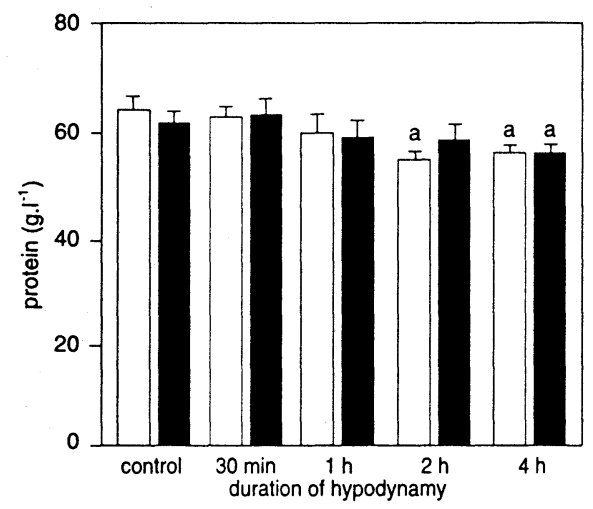

Fig. 11. Effect of hypodynamy on serum protein concentration (mean + S. E. M.)

Open bars - nonselected line

Full bars - selected line

$\mathrm{n}=8$

$\mathrm{a}-\mathrm{p}<0.05$ in comparison with control within single line

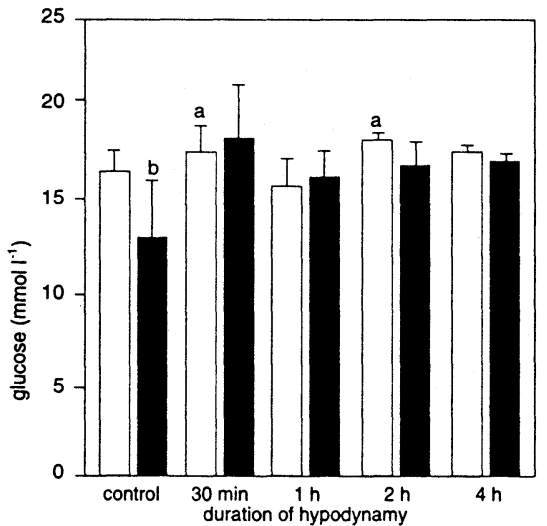

Fig. 12. Effect of hypodynamy on plasma glucose concentration (mean + S. E. M.) Open bars - nonselected line Full bars - selected line $\mathrm{n}=8$ $\mathrm{a}-\mathrm{p}<0.05$ in comparison with control within single line b - $p<0.05$ in comparison with nonselected line

The plasma cholesterol concentrations did not differ between both lines and there were no changes determined during the whole 4 hours lasting hypodynamy (Fig. 13).

The basal levels of plasma triacylglycerols of selected line were in comparison with nonse-

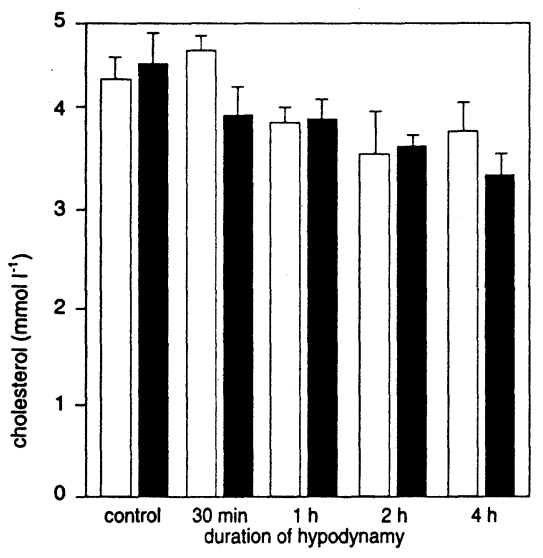

Fig. 13. Effect of hypodynamy on plasma cholesterol concentration (mean + S. E. M.)

Open bars - nonselected line

Full bars - selected line $\mathrm{n}=8$

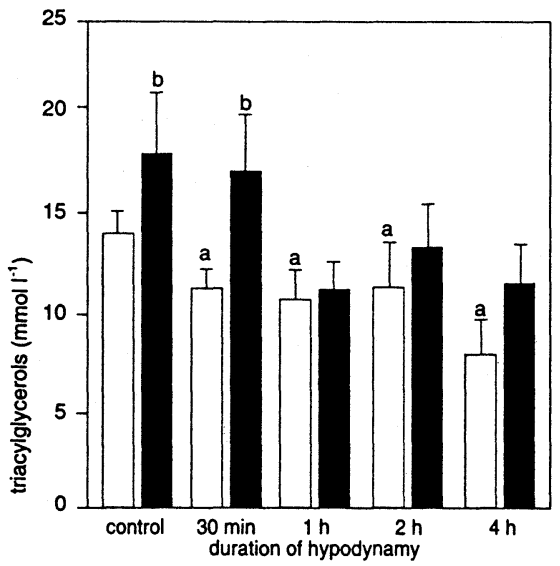

Fig. 14. Effect of hypodynamy on plasma triacylglycerol concentration (mean + S. E. M.) Open bars - nonselected line Full bars - selected line $\mathrm{n}=8$

$\mathrm{a}-\mathrm{p}<0.05$ in comparison with control within single line

$\mathrm{b}-\mathrm{p}<0.05$ in comparison with nonselected line

lected one significantly higher (Fig. 14). After the exposure of quail to all tested hypodynamy durations the significant decline of triacylglycerols in nonselected line was recorded. In selected line of quail no significant changes in triacylglycerol concentration were determined. 


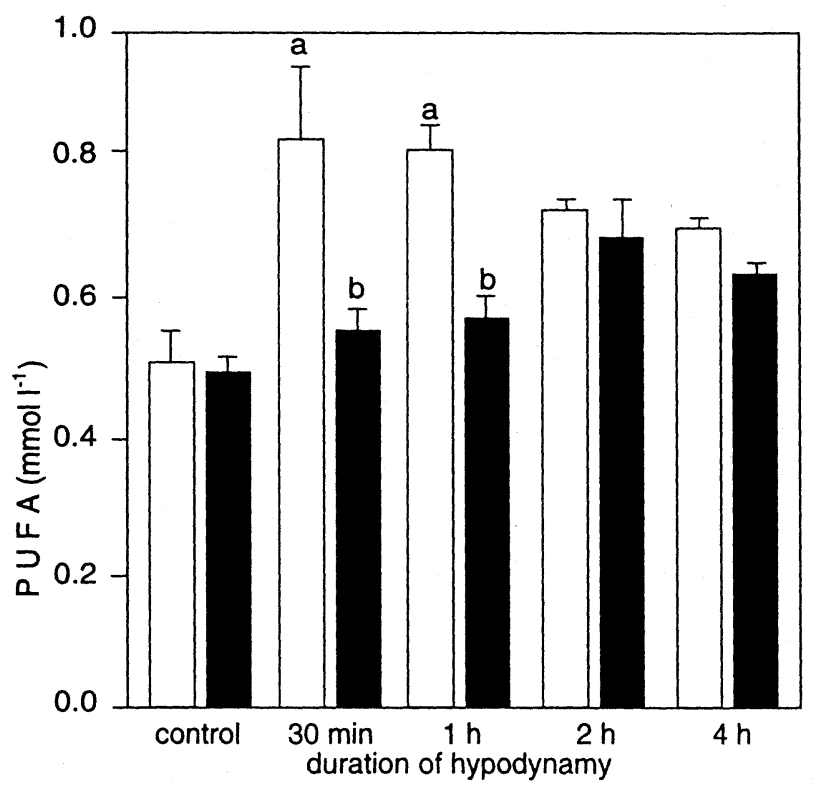

Presented results demonstrate that the selection for maintaining a high egg production under hypodynamy conditions do not affect the response of gonads only, but modify also the response of other endocrine glands and parameters of intermediary metabolism.

Fig. 15. Effect of hypodynamy on plasma polyunsaturated fatty acids (mean + S. E. M.) Open bars - nonselected line Full bars - selected line $\mathrm{n}=8$

$\mathrm{a}-\mathrm{p}<0.05$ in comparison with control within single line

$\mathrm{b}-\mathrm{p}<0.05$ in comparison with nonselected line

\section{Selekcia prepelíc japonských na rezistenciu k hypodynamii a fyziologické dôsledky selekcie}

Počas dvanástich generácií sme selektovali voči hypodynamii rezistentnú líniu prepelíc japonských. Selekčným kritériom bola produkcia vajec v priebehu štrnástdňovej hypodynamie. V každej generácii polovica prepelíc s najvyššou znáškou vajec bola použitá pre vytvorenie dalšej generácie. Priemerná znáška vajec počas hypodynamie bola v selektovanej línii vyššia ako u neselektovaných jedincov. Počas hypodynamie sme pozorovali nižší pokles telesnej hmotnosti u selektovanej línie než u neselektovanej, u selektovanej bol však zvýšený aj prijem potravy. Hmotnost vajec, najmä hmotnost škrupiny, oplodnenost', a liahnivost bola v chove selektovanej línie vyššia. Signifikantne sa líšila reakcia endokrinného systému medzi neselektovanou a selektovanou líniou prepelíc japonských na krátkodobú hypodynamiu reprezentovaná hormónmi (katecholamíny, tyreoidálne hormóny, estradiol), ako aj indikátory intermediárnho metabolizmu (bielkoviny, glukóza, cholesterol, triacylglyceroly, polynenasýtené mastné kyseliny).

\section{Селекция японских перепелок к устойчивости к гиподинамии и физиологические последствия отбора}

Втечение двенадцати поколений проводили отбор устойчивой линии японских перепелок по отношению к гиподинамии. Критерием отбора стала продукция яиц в течение двухнедельной гиподинамии. В каждом поколении половину перепелок с максимальной продукцией яиц использовали для создания следующего поколения. Средняя носка яиц в ходе гиподинамии у отбираемой линии была выше продукции неселектированных перепелок, однако у отборной линии наблюдалось увеличение доли питания. Масса яиц, в основном, масса скорпупы, оплодотворенность, вылупливаемость была больше у селектированной линии. Явно наблюдали разницу реакции эндокринной системы между неселектированной и отборной линиями япо- 
нских перепелек на кратковременную гиподинамию, представляемую гормонами (катехоламинами, кортикостероном, гормонами щитовидной железы, эстрадиолом), а также индикаторами интермедиарного метаболизма (белками, глюкозой, холестерином, триацилглицерилами, полуненасыщенными жирными кислотами).

\section{References}

BARASH, H., AKOW, S. 1987: Clin. Chem. 337:176-179

BARTELS, H., GOURLET, V., PERRAMON, A., PIERE, M.,STUPFEL, M. 1985: Aviat. Space Environ. Med. 56:976-984

BODA, K. 1993: Acta vet. Brno 62:S91-S94

DARDEN, J. R., MARKS, H. L. 1988: Poultry Sci. 67:1111-1122

ETCHES, R. J 1976: Steroids:763-773

FÖLDES, O., HRCKA, R., VELIMSKÝ, J., KOKEŠOVA, H., LANGER, P., LIŠTIAKOVÁ, M. 1978: Biochem. Clin. Bohemoslov. 7:143-151

FRÁNEK, M., HRUŠKA, K. 1980: J. Steroid Biochem. 13:675-679

KOVALENKO, E. A. 1977: Biol. Med. 11:3-9

JURANI, M.,VYYBOH, P., LAMOŠOVA, D., BODA, K., NVOTA, J. 1980: In: Scientific Works of the Institute of Animal Physiology of the SASci. Ed. K. Boda. Veda, Bratislava, pp. 231-244

JURÁNI, M.. KMECOVÁ, D., VÝBOH, P., NVOTA, J. 1981: In: Recent Advances of Avian Endocrinology. Eds. G. Pethes, P. Péczely, P. Rudas. Akadémia Kiadó, Budapest, pp. 43-51

JURANI, M., VÝBOH, P., LAMOŚOVÁ, D., BAROSKOVA, Z., SOMOGYIOVA, E. 1983: The Physiologist 26:145-148

JURANI, M., KISS, A. 1984: Br. Poult. Sci. 25:91-98

LOWRY, O. H., ROSEBROUGH, N. J., FARR, A. L., RANDALL, R. J. 1951: J. biol. Chem. 193:265-275

MAEDA, Y., KAWABE, K., OKAMOTO, S., HASHIGUCHI, T. 1994: Br. Poult. Sci. 35:135-144

PESCE, V. H. D., LEMERCERRE, M., STUPFEL, A., PERRAMON, A., GOURLET, V. 1987:In: Proceedings of the 3rd European Symposium on Life Sciences Research. Graz, pp. 341-343

SATTERLEE, D. G., JOHNSON, W. A. 1988: Poultry Sci. 67:25-32 